\title{
ONE FUNGUS ONE NAME: A PLANT PATHOLOGIST'S VIEW
}

Some eight months have gone by since the significant "One fungus = One name" $(1 \mathrm{~F}=1 \mathrm{~N})$ symposium was held at the historic home of the Netherland's Academy of Science, Trippenhuis, in Amsterdam. This period might well go down in history as amongst the most traumatic, exciting, and important in the history of fungal taxonomy. The outcomes will undoubtedly influence the field and the many associated disciplines that rely upon it for decades, if not posterity.

I had the privilege of being invited to present one of the introductory lectures at the $1 \mathrm{~F}=1 \mathrm{~N}$ symposium. Given the level of tension concerning the topic, I am not sure that I was particularly excited about doing so at the time. Yet as a plant pathologist and academic, I have had to grapple with the confusing issue of fungi having more than one name, sometimes even different species names, for most of my career. Like many other plant pathologists, in my case working on trees, I have been confronted by farmers and foresters who have been frustrated, sometimes irritated, by the confusing names that they have had to contend with, while attempting to reduce the impact of plant diseases. Likewise, students in classes have been baffled by the complexities surrounding the dual nomenclature linked to anamorph/teleomorph connections and further complicated by pleomorphism in the asexual morphs of fungi. After many years of debate, often heated, the $1 \mathrm{~F}=1 \mathrm{~N}$ symposium in Amsterdam provided us with a perfect forum to debate the possibility of abandoning the dual nomenclature for the fungi.

The turning point towards abandoning Article 59 and adopting a single name nomenclature arose as a result of DNA sequence data becoming increasingly available to mycologists. Effectively the "rules" dictated by the Code became restrictive, often redundant. Out of sheer frustration, some plant pathologists (see Crous et al. 2006) found it necessary to sidestep these regulations in order to present a meaningful taxonomy for important agents of plant disease. As John Taylor, the opening speaker at the $1 \mathrm{~F}=1 \mathrm{~N}$ symposium aptly stated, in seeking to abandon the dual nomenclature for fungi, we were in reality dealing with a situation where the proverbial "horse had already bolted" (Taylor 2011). My presentation followed Johns' and, while also expounding on the inevitable demise of a dual nomenclature, as a plant pathologist and practitioner using mycology, my questions focussed mostly not on $1 \mathrm{~F}=1 \mathrm{~N}$, but the issue of WHICH NAME we might most effectively use.

The $\mathrm{IF}=1 \mathrm{~N}$ symposium presented contradictory views regarding the opportunities and the hazards of abandoning a dual nomenclature for the fungi. The debates were lively, sometimes heated, and the event culminated in the drafting of the Amsterdam Declaration later published in this journal (Hawksworth et al.
2011). It also precipitated the publication of a contrary view (Gams et al. 2011), which also had a large number of supporters. But most importantly, I believe that these debates provided the material that was essential for the all-important deliberations that would follow during discussions regarding the next edition of the Code at the International Botanical Congress that was to follow in Melbourne in July.

The watershed discussions in Melbourne regarding the future of the taxonomy of the fungi are over. And the outcomes

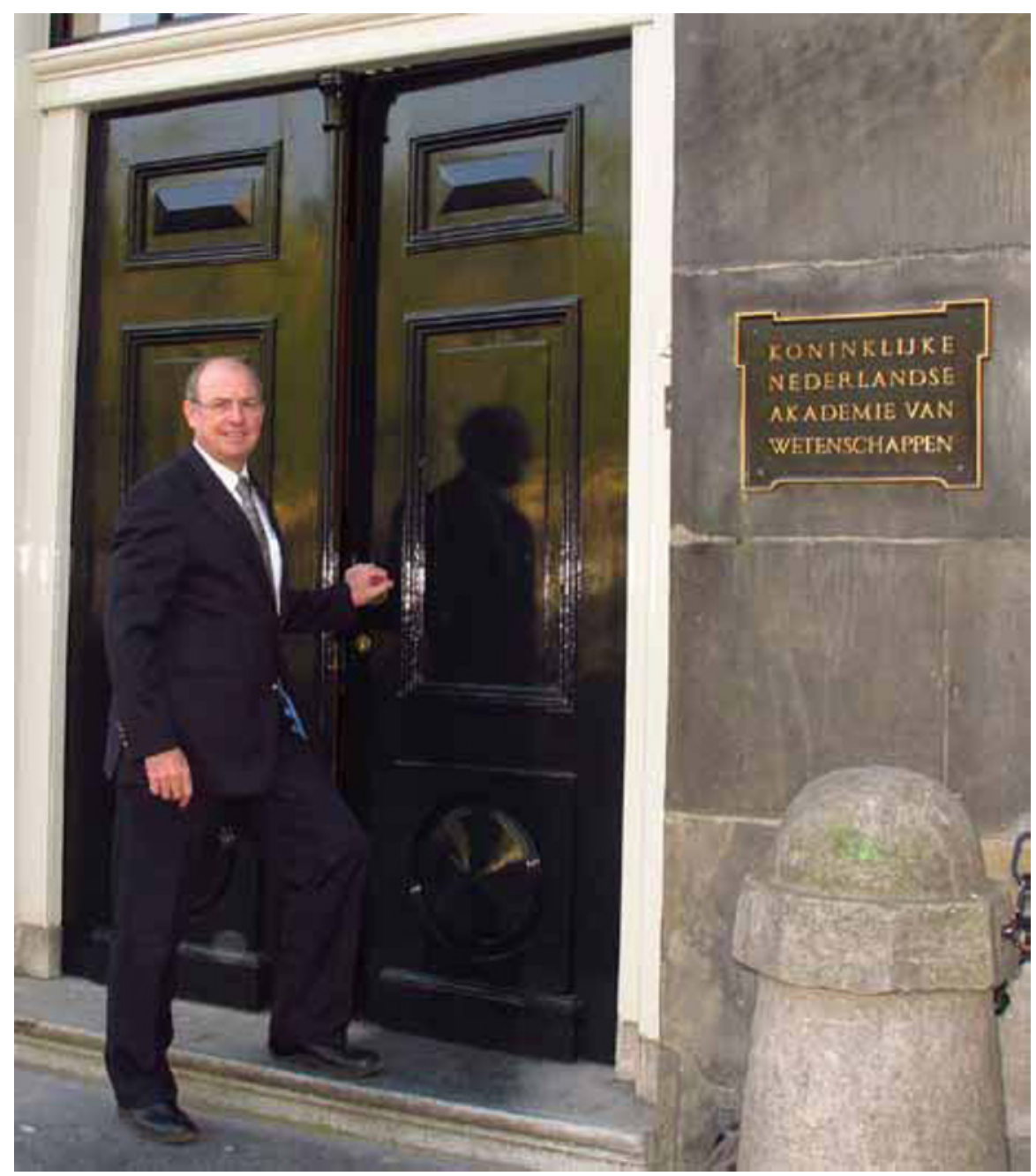

Mike Wingfield entering the rooms of the Royal Netherlands Academy of Arts and Sciences in Amsterdam for the One Fungus = One Name symposium on 19-20 April 2011. 
(Hawksworth 2011, Knapp et al. 2011, McNeill et al. 2011, Norvell 2011) are monumental to say the least. Some of us closely involved in the debate and that could not be in Melbourne received "blow by blow" accounts of the proceedings from Scott Redhead. Scott played an enormously important part in the debate, and had served as Secretary to a Special Committee established by the previous Congress in Vienna in 2005 to address this issue which had sadly failed to reach a consensus.

From 1 January 2013, Article 59 will no longer provide for the separate naming of different morphs of the same fungus; all fungi will from then have only one correct name. I am absolutely convinced that that this will substantially promote our credibility with the practitioners of mycology. Certainly, in my situation, this will especially support plant pathologists and our stakeholders that rely on us to manage plant diseases (see Wingfield $e t$ al. 2011). But the real work post-Melbourne has yet to be done. The process towards deciding WHICH NAMES we use for the fungi now faces us, and another meeting at the Trippenhuis in April 2012 lies ahead to address this issue. Under the revised rules adopted in Melbourne, it will fortunately now be possible to develop approved lists of names with special protection to help minimize disruptions to the mycological community. Nevertheless, for some fungi, this is likely to be a road not entirely smooth. But it is a road towards a long-awaited natural classification for the fungi that had to be embarked on. Let the games begin.

Crous PW, Slippers B, Wingfield MJ, Rheeder J, Marasas WFO, Philips AJL, Alves A, Burgess TI, Barber P, Groenewald JZ (2006) Phylogenetic lineages in the Botryosphaeriaceae. Studies in Mycology 55: 235-253.

Gams W, Jaklitsch W, Agerer R, Aguirre-Hudson B, Andersen B, et al. (2011) A critical response to the 'Amsterdam Declaration'. Mycotaxon 116: 501-513.

Hawksworth DL (2011) A new dawn for the naming of fungi: impacts of decisions made in Melbourne in July 2011 on the future publication and regulation of fungal names. MycoKeys 1: 7-20; IMA Fungus 2: 155-162.

Hawksworth DL, Crous PW, Redhead SA, Reynolds DR, Samson RA, Seifert KA, Taylor JW,
Wingfield MJ, et al. (2011) The Amsterdam Declaration on Fungal Nomenclature. IMA Fungus 2: 105-112; Mycotaxon 116: 491-500.

Knapp S, McNeil, J, Turland NJ (2011) Changes to publication requirements made at the XVIII International Botanical Congress in Melbourne - what does e-publication mean for you? Taxon 60: 1498-1501; Mycotaxon 117: in press. McNeill J, Turland NJ, Monro A, Lepschi B (2011) XVIII International Botanical Congress: preliminary mail vote and report of Congress action on nomenclature proposals. Taxon 60: 1507-1520.

Norvell LL (2011) Fungal nomenclature. 1. Melbourne approves a new Code. Mycotaxon 116: 481-490.

Taylor JE (2011) One Fungus = One Name: DNA and fungal nomenclature twenty years after PCR. IMA Fungus 2: 113-120.

Wingfield MJ, de Beer ZW, Slippers B, Wingfield BD, Groenewald JZ, Lombard L, Crous PW (2011) One fungus one name promotes progressive plant pathology. Molecular Plant Pathology : in press.

Michael J. Wingfield

(Mike.Wingfield@fabi.up.ac.za) 